\title{
Transmitting Local Wisdom through Minahasan Folkore
}

\author{
$1^{\text {st }}$ Merlin Maya Maukar \\ English Language and Literature \\ Department \\ Universitas Negeri Manado \\ Manado, Indonesia \\ merlinmaukar@unima.ac.id \\ $4^{\text {th }}$ Lucille M Takalumang \\ Music Art Department \\ Universitas Negeri Manado \\ Manado, Indonesia \\ Lucciletakalumang@gmail.com
}

\author{
$2^{\text {nd }}$ Agustine Clara Mamentu \\ English Language and Literature \\ Department \\ Universitas Negeri Manado \\ Manado, Indonesia \\ mamentuclara@unima.ac.id
}

\author{
$3^{\text {rd }}$ Meyny S C Kaunang \\ Music Art Department \\ Universitas Negeri Manado \\ Manado, Indonesia \\ kaunangmeyny_SC@yahoo.com
}

\begin{abstract}
Past inheritance is not always a relic to be preserved and kept in the museum to be watched and admired only. There are some that should be extracted to understand the values lie beneath and furthermore those extracted materials could be transmitted to be a guide and support in life. This writing is intended to extract the local wisdom that can be found in some of the folklores that circulated among the people particularly in Minahasa, as well as to figure out ways of transmitting it. This is a qualitative research where data are consisting of words rather than numbers. The primary data are the folklores specifically folksongs, folktales and proverbs that can be found in Minahasa, one for each category, and the secondary data are some information about Minahasan social and cultural life that can be taken from some books and internet websites. In analyzing the data, the theory of interpreting folklore introduced by Alan Dundes will be used. Having analyzed the object material, it is found that the local wisdoms carried by the folklores are valuable to give insight for people in Minahasa. Behind each example of folktale, folk proverb and folksong lies great moral lesson. Unfortunately, those have been almost forgotten by people in Minahasa. Therefore, one of the ways of reminding the Minahasans of their traditional inheritance could be by transmitting them through local subject in schools. By introducing the folklores to people since their early years, perhaps they will also learn to understand the local wisdom lies behind those folklores, and practiced them at daily basis.
\end{abstract}

Keywords : folklores, local wisdom, transmitting, Minahasan

\section{INTRODUCTION}

Folklore is generally known as social behaviors, customs, traditions, and beliefs which has been inherited and survived in a certain community for generations. Those could be the signifiers that distinguish them with other communities. Brunvand strengthened it by stating that folklore "can be defined as those materials in culture that circulate traditionally among members in any group in different versions, whether in oral form or by means of customary examples"[1]

There are so many "materials in culture" recognized as folklore, therefore to make a specification this writing is only to analyze several materials taken from one group of folklore that is verbal folklore. The categorization is taken from Brunvand's idea of dividing folklores into three groups: (1) Verbal Folklore which is includes of folk speech, folk proverbs and proverbial saying, folk riddles, folk rhymes and other traditional poetries, folk narratives (myth, legend, tale, etc) and folksongs; (2) Partly Verbal Folklore which is includes of beliefs, superstitions, folk games, folk dramas, folk dances, folk customs and folk festivals; (3) Non Verbal Folklore which is includes of folk architectures, arts, crafts, costumes, foods, gestures, folk music. However, Brunvand added that 'those categories can overlap for example a tale as a verbal folklore can be studied along with the facial expressions, gestures and audience reactions, which belong to the non verbal, as the tale is being told' [1]. As explained above, the category of verbal folklore may consist of folk speech, folk proverbs and proverbial saying, folk riddles, folk rhymes and other traditional poetries, folktales, folk legend, myth and folksongs. Because of the variety of folklore therefore among those categories only folktales, folksong and folk proverbs will be taken as the object material of this writing.

Folklore consists of two important terms, those are, folk and lore. The term 'folk' refers to people who involve in particular community and who share at least one common factor. Dundes states that 'it does not matter what the linking factor is - it could be a common occupation, 
language or religion - but what is important is that a group formed for whatever reason will have some traditions which it calls its own' [2]. Meanwhile, the term 'lore' refers to the folk tradition which inherited orally from one generation to the next generation or imitated from gestures or mnemonic devices [3]. In this case the folk is Minahasan people. It is simply just because the writer is a Minahasan who intrigues to dig out her own buried inheritance and share them to others.

As an introduction, Minahasa is located in Northern part of Sulawesi Island. At present, when having looked as an area, Minahasa is a regency of North Sulawesi Province. The capital city is Tondano. Starting from 2001 the regency was divided into Minahasa, South Minahasa, North Minahasa, Southeast Minahasa, and Tomohon City. However, when having looked as an ethnic, Minahasa is the dominant ethnic in North Sulawesi. The inhabitants in Manado, Bitung and Minahasa are mostly Minahasan people. This writing is intended to extract the local wisdom that lies behind verbal folklores specifically folktales, folksongs and folk proverbs circulated among the people of Minahasa.

There are many folklores circulate in Minahasa but those have not been compiled yet, therefore the folklores taken as the object material here are those which are familiar to the writer. Those folktales, folksongs and proverbs have been accompanied her since childhood. Folktales were use to be told as bed time stories, folksongs were sang as lullaby and proverbs were told as advise in life. When giving a lot of thought, those are very suitable to share as a counter to many stories which are not in line with the local value and traditional customs. In other words, in sharing the folktales, folk proverbs and folksongs, Minahasan people can be reminded of the local wisdom wished to be transmitted by the older generation that lies behind those folklores.

\section{II.RESEARCH METHODOLOGY}

\section{A. Method of Research}

This is a qualitative research where data are consisting of words taken from the object material of this research. As explained by Bogdan and Biklen that qualitative research is descriptive. The data are collected in form of words and pictures rather than numbers. The written result of the research contains quotation from the data to illustrate the presentation [4].

2. Techniques of Research

The research technique used is literature study, because all data is taken from books and other sources. The literature study in question is to obtain complete information and to determine the actions to be taken as important steps in scientific activities.

3. Data Source

The primary source of the data in this study is taken from Minahasan Folklore: folktale, folk proverbs and folksongs which has been passed through generations and the author also uses books on literature and folklore.

\section{RESULTS AND DISCUSSION}

This discussion is divided into three parts, each discuss the category of folklore as chosen above: folktales, folk proverbs and folksongs.

\section{FOLKTALES}

There are many folktales circulated in Minahasa, this one is only the example of those. From those Minahasan folktales, many have been almost forgotten by the youngster. They are more familiar to the character of Cinderella, snow white, or Alladin then the characters in Minahasan folktales such as Magiyan, the central character in the folktale below.

This old tale in Minahasa tells about a young girl named Magiyan. This young girl always love to sing songs to the gods. One night while singing songs to gods she was startled when realized that it was very late, then she soon hurried home. When she arrived home she found out that the stairs had been lifted up. As a punishment for coming home very late, they did not let down the stairs for her. She called out her parents begging for their forgiveness but they did not let her come up to the house. His father asked Magiyan to go to her sister's house. Her sister did not want to accept her and asked her to go to her uncle's house. At her uncle's house they could not let her got up as well, because it was very late and they were worried she was asked to stay, but she had to sleep with the dogs. Magiyan, annoyed by the dogs' fleas, could not sleep at all so she decided to go out and singing songs to gods sadly while waiting for the sunrise. When the sun began to rise, a golden rope descended from the sky for Magiyan to climb up for she got the favor of gods because of her songs. While magiyan climbing up the rope her parents cried out,"Magiyan, come back, come back! We realize that you're innocent, we will make a ceremony to give back your honor." But Magiyan went higher and higher until she reached the up world. The gods gave her a bath to sanctify her and held a ceremony for her. As a gift she will stayed at the sky, united with the universe; her face became the sun, her head became the moon and her body became the stars that shine day and night to give light to the earth.

Having analyzed the story, there are some local wisdom that can be extracted from this folktale. Those are:

1. Forgiveness

One of the points of this story is to teach about forgiveness, how people should be able to develop ability to forgive other people's fault. Even though someone has done mistakes and it is bad enough, but when that person has realizes the fault and ask for forgiveness, it can be given. Stubborn act can bring regret.

Magiyan had done mistake by coming home very late, yet she is still a young girl who cannot defend herself from bad things around the house. Her parents showed no mercy and refused to let her came inside the house, so did her sister and her uncle. The girl has begged over and over again from house to house of her relatives but they could not spare any forgiveness therefore she found sanctuary from others. Finally, her parents regret for they could not have the chance to meet their daughter again.

2. Obedience 
Children are supposed to listen to parents. This tale told about how a child forgets her parents' advice to come home early. Whatever reason that she had, Magiyan had forgotten the advice of not coming home late, which is why her parents do not allow her to go up the house.

Ancient house of Minahasa were built high up and the stairs are flexible. It can be lifted up to forbid unexpected people to enter the house. As described by Wallace, the ancient Minahasan people are "savages who lived in the forests wearing strips of barks. They were also headhunters and sometimes cannibal. They built their houses high up from the ground supported by poles as thick as two adults embrace to defend themselves from the enemy's attacks." [5]. The image of Minahasan people at that time was wild. They were thought of as savages, headhunters and cannibals who always fought with their enemies. Their habitat was in the forest. That is one reason why Magiyan's parents lifted up the stairs and do not let it stay down, to provide safety for the rest of the family. The same thing also happened to her sister and her uncle. They could not let down their stairs. The uncle only let Magiyan sleep with the dogs under the house.

Obedience is one thing that should be taught to children since their early years. This tale can be an example for children to obey parents' advice. I remember my mother use to told me this story and I will be very afraid imagining my head becoming the sun, my face becoming the moon and my body becoming the stars if I do not listen to my parents' advice.

\section{FOLK PROVERBS}

"Saru lutu' taburi mata",

(Facing in front when it is cooked, facing backward when it is raw)

In society where working together or in Indonesian gotong royong is a custom to be practiced in daily basis, this proverb can be a mock for those who are lazy or have the bad habit of taking advantages of other people or in Manadonese called pancuri tulang. It is some kind of satire to remind people of the good thing and the bad thing to do.

Minahasa has tradition of working together in almost every part of social life. People are participating voluntarily to help out. Here are some examples that can be taken in relation with understanding the local wisdom that lies behind the proverb.

1. Mapalus

Mapalus is a tradition of working together in field. People who participate usually have land or field to be cultivated. They cultivate each person's field in turn. When working together they can finish faster and it can be done cheerfully because they usually sing while working. The proverb remind people that it is not good to come late when work is almost done.

2. Sumakey

Another form of working together is called Sumakey. It is a tradition of bringing food at a funeral. The purpose is to help out the family in grief. They do not have to worry about preparing food for people who are participated such as those who carry the decease person to the graveyard, people who prepare the ceremony, or even relatives from far places. All those food will be eaten together after they brought the deceased person to the graveyard.

\section{Masawangan}

The tradition of working together is also occurred in almost every activity of preparing food for parties or other occasions in Minahasa. People will gather, sometime bringing their own knife or other cooking utensils and help out chopping meats, slicing onions, pangi leaves, kotey and other ingredients. Breakfast, lunch and dinner usually prepared by the host and enjoyed together by all the helpers along with their children. This opportunity is sometimes used by those pancuri tulang to eat free meals. Those who are coming around just to enjoy the food are teased by the proverb saru lutu', taburi mata' means they are coming around just to enjoy the food when it is cooked but they did not help out in preparing the meal.

\section{“ Kalelewo' Kaleleos “}

(Got unlucky, got lucky)

This proverb teach people to be grateful, whatever they got they should believe that it is their part. Do not envy of other people's luck because as it is said there are times when you got lucky but there are times when you got unlucky.

This proverb is usually applied in several occasions. When a person comes late into a place and miss the good part of for example food or show, people will say this proverb either to tease or to comfort.

\section{FOLKSONGS}

Esa Mokan

Esa mokan genangku wia niko

Tea mo marua rua genang e karia

Mengale ngale uman wia si opo wailan

Pakatuan pakalawiren kita nuaya

Free translation:

$1^{\text {st }}$ line

Esa mokan genangku wia niko

(There's one thing I will remind you)

$2^{\text {nd }}$ line

Tea mo marua rua genang e karia

(Do not think of other anymore)

$3^{\text {rd }}$ line

Mengale ngale uman wia si opo wailan

(Remember of what opo wailan said)

$4^{\text {th }}$ line

Pakatuan pakalawiren kita nuaya

(May we can be given a long and healthy life)

This song is sung to remind someone to be faithful. It is said in the $1^{\text {st }}$ line that there is one thing to be reminded. The thing is clearly stated in the $2^{\text {nd }}$ line, that is to be faithful or not to think about anyone else. $3^{\text {rd }}$ line explains that faithfulness can be kept with the help of Opo Wailan, therefore it should be asked to Opo Wailan. When it is granted, then the healthy and long life will be given as stated at the $4^{\text {th }}$ line.

The term Opo Wailan is referring to the ancient way of addressing God. Minahasa's traditional religion is called Makatana which means the knowledge from the owner of the land or earth. They recognized one divine God called Opo Empung Wailan Wangko or Empung Renga-rengan, the source of all essence of life who own the earth and give people knowledge. In addition there were also Opo-opo or the ancestors who protected and guided them in all aspects 
of life since they were born [6]. The folksong above signified Minahasans religious life, God is always taken part in all aspects of life. As described in the song, when people put their matter in God's hand, He will help, guide and protect them in all things in life. Just ask and it will be given to you.

Lesson to be learned from this folksong is about faithfulness. The first one is described in the $2^{\text {nd }}$ line as faithfulness of man to man and the second one is described in the $3^{\text {rd }}$ line as faithfulness of man to God. It is interrelated because as inferred in the $4^{\text {th }}$ line, with man's faith to God they will be strengthened and blessed. Thus, side by side the faith to man and the faith to God should be confined to bring the best result in life.

From the traditional inheritances passed by the elders, those words of wise have gone through times. As it is known, time is a good teacher to teach us what is good and what is wrong. It can also be understood that many generations have shared them, and proved to be a good guidance that bring them to the best chosen destination.

But then, it is a shame that many local people who suppose to inherit those wisdoms have forgotten and replaced them with many foreign materials transmitted through sophisticated media. The alteration of some traditional inheritance and local wisdom has resulted in the vanishing of Minahasan real culture. Hetty Palm made a statement that there is no other place in Indonesia that had their culture so fast and completely disappeared as Minahasan culture (7).

The lost of understanding about those local wisdom has to be cured and fixed. It is not just for our own good but it is for the sake of our generations to come. If this generation does not make an effort to fix this problem, then it is a big possibility that there will be a lost generation in the future, the lost generation who forgot their past inheritance and finally forgot their identity as Minahasan people.

One of the ways to preserve Minahasan traditional inheritance in order to keep Minahasan true identity, I think, is to share the folklores which contain local wisdom. Those folklores can be taught in schools, after recorded in books, as one of the local curriculum. Nowadays, people are more attractive in learning English than their own dialect, thus probably the best way is to translate those folklores in English along with the values inside them and then use them as English teaching materials. Hopefully it can help to maintain what have been left by the ancestors namely good value, guidance, and local wisdom of Minahasa.

\section{III.CONCLUSION}

As a conclusion of this writing, the local wisdom can be viewed as guide in life. Life without guidance is like a car without steering wheel, it cannot bring us to the correct direction instead it can crash. The wrong direction will bring us to the wrong destination, so does the correct direction will take us to correct destination.

Many good views have been revealed just from few examples above. From the story of Magiyan, we can learn about forgiveness and obedience; from the folk proverbs described above, the work culture of Minahasan people can be discovered; the folksong taught us to be faithful either to God or to man. Those are only tiny examples of the values available inside of Minahasan folklore.

There are more of good views have been kept inside of Minahasan folklores that can be taught to the young generations. Possibly, introducing those folklores to students in schools through books of English learning can be one interesting way. It is to preserve the long lost inheritance of Minahasa and bring back the local wisdom to the society [7].

\section{REFERENCES}

[1] J. H. Brunvand, The Study of American Folklore: An Introduction. New York: W.W.Norton \& Co.Inc. Print, 1978.

[2] A. Dundes, Interpreting Folklore. USA: ndiana University Press, 1980 .

[3] J. Dananjaya, Folklor Indonesia: Ilmu Gosip, Dongeng dan lainlain. Jakarta: PT Temprint, 1984.

[4] K. Bogdan, R.C. and Biklen, S, Qualitative Research for Education: An Introduction to Theory and Method New York:Pearson Education Group. 2003., (4th editi. New York: Pearson Education Inc, 2003.

[5] A. R. Wallace, The Malay Archipelago: The Land of Orang Utan and The Bird Paradise. A Narrative of Travel with Studies of Man and Nature. London: Macmillan and Co., 1869.

[6] J. Wenas, Sejarah dan Kebudayaan Minahasa. Manado: Institut Seni Budaya Sulawesi Utar, 2007.

[7] H. Palm, Ancient Art of the Minahas. Jakarta: Italian Embassy, 1961 . 